\title{
23. INTERSTITIAL WATER STUDIES, DEEP SEA DRILLING PROJECT LEG 59
}

\author{
Joris M. Gieskes and Jeff Johnson, Scripps Institution of Oceanography, \\ University of California, San Diego, La Jolla, California
}

\begin{abstract}
Interstitial water studies of samples from Leg 59 show small concentration variations from sea water in Sites 447 and 451 but very large concentration changes in Site 450. A general analysis of calcium concentration gradients in this region is presented, which emphasizes the anomaly presented by the interstitial water chemistry of Sites 53 and 450 in the Parece Vela Basin. An analysis of concentration changes in $\mathrm{Ca}, \mathrm{Mg}, \mathrm{Sr}, \mathrm{Li}, \mathrm{Mn}$, and $\mathrm{Si}$ indicates that reaction zones associated with high concentrations of dissolved silica can account for these observations.
\end{abstract}

\section{INTRODUCTION}

During Leg 59, interstitial water samples were collected at Sites 447 through 451 (Fig. 1). Shipboard analyses of $p \mathrm{H}$, alkalinity, and calcium and magnesium indicated slight concentration-depth variations in Sites 447 and 451 and large concentration changes in Site 450. We decided to make more detailed analyses of samples from these three sites, as they could be expected to show

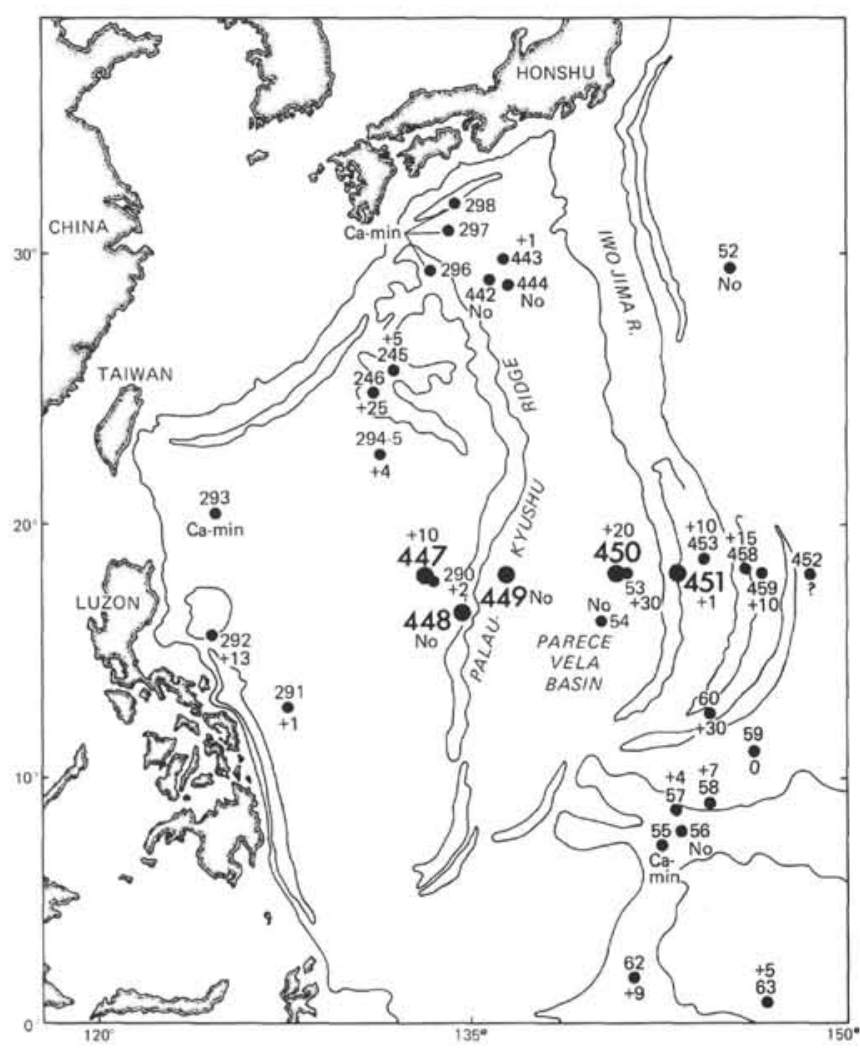

Figure 1. Area map of Leg 59. (Site numbers are associated with observations on calcium gradients: No $=$ no gradient $; \mathrm{Ca}-\mathrm{min}=$ calcium minimum associated with rapidly deposited sediments; other gradients with + sign indicate average calcium gradients in $\mathrm{m} M / 100 \mathrm{~m}$, increasing in concentration with depth.) concentrations different from those in sea water for other dissolved constituents.

Analyses were carried out using the procedures described by Gieskes (1974) and Gieskes and Lawrence (1976). Lithium was analyzed using a modification of the procedure described by Presley (1971). Sulfate analyses were carried out using a polarographic technique (Barnes et al., 1979; Luther and Meyerson, 1975). The data, including shipboard data, are presented in Table 1 .

\section{DISCUSSION}

In Figure 1, data on concentration-depth gradients of dissolved calcium are summarized for the entire region, $0^{\circ}$ to $40^{\circ} \mathrm{N}, 120^{\circ}$ to $150^{\circ} \mathrm{E}$. Minima in dissolved calcium are often observed in rapidly deposited sediments ( $\geq 4 \mathrm{~cm} / 1000 \mathrm{yrs})$, both of biogenic and of terrigenous nature. Concentration increases in dissolved calcium are more often associated with slowly deposited sediments; these increases are ascribed to alteration of volcanic material in the sediments (Gieskes and Lawrence, in preparation) and/or in the underlying basement (McDuff, 1978; in preparation). McDuff (1978) noted a gradual appearance of observable concentration gradients with increasing basement age, with sites less than $20 \mathrm{~m}$.y. old showing relatively few gradients. This observation has been interpreted as indicating that there was increased communication between the ocean and the underlying basalts through the sediment column, the concentration gradients often being the result of transport processes only (McDuff and Gieskes, 1976; McDuff, 1978). On the other hand, sites with noticeable contributions of volcanic material often do show appreciable concentration gradients even in relatively young sites.

Basement in the Parece Vela Basin is generally younger than $25 \mathrm{~m} . \mathrm{y}$. whereas basement in the West Philippine Basin is considerably older. Thus it is not surprising to note a general absence of concentration gradients in the Parece Vela Basin and fairly large concentration gradients in most of the West Philippine Basin. The problem, however, is that although at many sites in the region of the Parece Vela Basin (e.g., Sites 
Table 1. Interstitial water composition, Leg 59.

\begin{tabular}{|c|c|c|c|c|c|c|c|c|c|c|c|c|c|c|}
\hline $\begin{array}{c}\text { Hole } \\
\text { (intervals in cm) }\end{array}$ & $\begin{array}{l}\text { Sub-bottom } \\
\text { Depth } \\
\text { (m) }\end{array}$ & $p \mathrm{H}^{\mathrm{a}}$ & $\begin{array}{c}\text { Alk }^{\mathrm{a}} \\
(\mathrm{meq} / 1)\end{array}$ & $\begin{array}{c}\mathrm{Cl}^{\mathrm{a}} \\
\left(10^{-3}\right)\end{array}$ & $\underset{\left(10^{-3}\right)}{\mathrm{S}^{\mathrm{a}}}$ & $\begin{array}{l}\mathrm{Ca}^{\mathrm{a}} \\
(\mathrm{mM})\end{array}$ & $\begin{array}{l}\mathrm{Mg}^{\mathrm{a}} \\
(\mathrm{mM})\end{array}$ & $\underset{(\mathrm{m} M)}{\mathrm{Sr}}$ & $\begin{array}{c}\mathrm{Mn} \\
(\mu M)\end{array}$ & $\underset{(\mu M)}{\mathrm{Li}}$ & $\underset{(\mathrm{m} M)}{\mathrm{K}}$ & $\underset{(\mu M)}{\mathrm{Si}}$ & $\begin{array}{c}\mathrm{SO}_{4} \\
(\mathrm{mM})\end{array}$ & $\begin{array}{l}\mathrm{NH}^{\mathrm{b}} \\
(\mathrm{m} M)\end{array}$ \\
\hline \multicolumn{15}{|l|}{ Hole 447A } \\
\hline $4-3,140-150$ & 32.5 & 7.53 & 2.66 & 19.7 & 35.9 & 11.7 & 51.9 & 0.084 & 0 & 26.0 & 9.9 & 240 & 26.0 & 0.05 \\
\hline $6-5,140-150$ & 54.5 & 7.75 & 2.45 & 19.4 & 35.8 & 15.2 & 49.1 & 0.090 & 0 & 24.0 & 9.0 & 600 & 30.0 & 0.05 \\
\hline \multicolumn{15}{|l|}{ Hole 448} \\
\hline $1-2,113-128$ & 2.8 & 7.61 & 2.62 & 19.3 & 35.5 & 10.5 & 53.0 & & & & & & & \\
\hline $6-3,140-150$ & 47.5 & 7.62 & 2.72 & 19.3 & 35.8 & 11.2 & 53.0 & & & & & & & \\
\hline $11-4,140-150$ & 96.5 & 7.62 & 2.89 & 19.4 & 36.0 & 10.6 & 53.2 & & & & & & & \\
\hline $16-5,140-150$ & 145.5 & 7.63 & 2.87 & 19.7 & 35.8 & 10.6 & 52.7 & & & & & & & \\
\hline $21-3,135-150$ & 190 & 7.62 & 2.67 & 20.4 & 36.9 & 10.6 & 52.0 & & & & & & & \\
\hline $26-2,141-150$ & 236 & 8.50 & 2.65 & 19.2 & 35.5 & 9.9 & 46.2 & & & & & & & \\
\hline \multicolumn{15}{|l|}{ Hole 448A } \\
\hline $6-1,140-150$ & 253.5 & 7.56 & 2.67 & 19.1 & 36.0 & 11.0 & 51.1 & & & & & & & \\
\hline \multicolumn{15}{|l|}{ Hole 449} \\
\hline $2-2,140-150$ & 3 & 7.42 & 2.60 & 19.0 & 35.2 & 10.4 & 53.0 & & & & & & & \\
\hline $5-1,140-150$ & 30 & 7.79 & 2.93 & 19.2 & 35.5 & 11.2 & 52.0 & & & & & & & \\
\hline $8-4,140-150$ & 63 & 7.58 & 2.70 & 19.6 & 35.7 & 11.6 & 52.0 & & & & & & & \\
\hline $11-4,140-150$ & 91.5 & 7.64 & 2.67 & 19.8 & 35.6 & 11.1 & 52.1 & & & & & & & \\
\hline \multicolumn{15}{|l|}{ Hole 450} \\
\hline $1-4,144-150$ & 6 & 7.42 & 2.44 & 19.2 & 35.1 & 10.7 & 51.9 & 0.084 & 0.005 & 21.0 & 9.4 & 282 & 27.8 & 0.06 \\
\hline $5-2,144-150$ & 39 & 7.60 & 2.66 & 19.4 & 35.8 & 12.0 & 51.3 & 0.090 & 0.002 & 20.0 & 10.3 & 380 & 24.9 & 0.06 \\
\hline $12-2,140-150$ & 105.5 & 7.79 & 1.59 & 19.7 & 36.0 & 26.6 & 30.9 & 0.125 & 0.061 & 26.0 & 8.2 & 489 & 28.6 & 0.05 \\
\hline $16-3,140-150$ & 145 & 7.73 & 1.19 & 19.4 & 35.8 & 36.3 & 19.8 & 0.150 & 0.090 & 31.9 & 7.6 & 572 & 29.9 & 0.05 \\
\hline $20-1,140-150$ & 180 & 7.79 & 1.01 & 19.3 & 35.6 & 47.6 & 6.22 & 0.165 & 0.098 & 43.0 & 6.8 & 666 & 31.0 & 0.06 \\
\hline $24-3,140-150$ & 221 & 8.28 & 0.59 & 19.5 & 36.2 & 55.9 & 0.15 & 0.185 & 0.079 & 56.8 & 6.6 & 735 & - & 0.06 \\
\hline $28-3,140-150$ & 260 & 8.30 & 0.46 & 19.1 & 35.4 & 60.0 & 0.00 & 0.159 & 0.032 & 44.4 & 4.1 & 650 & - & 0.06 \\
\hline $32-3,140-150$ & 306 & 8.51 & 0.55 & 19.4 & 35.6 & 63.5 & 0.00 & 0.149 & 0.021 & 45.1 & 3.6 & 818 & - & 0.07 \\
\hline $32-5,140-150$ & 308 & - & - & - & - & - & - & - & 0.025 & - & - & 730 & - & 0.05 \\
\hline \multicolumn{15}{|l|}{ Hole 451} \\
\hline $2-4,140-150$ & 11.0 & 7.52 & 2.96 & 19.5 & 36.2 & 11.7 & 52.9 & 0.094 & 0.004 & 24.8 & 9.8 & 485 & 30.8 & 0.04 \\
\hline $5-3,140-150$ & 38.0 & 7.63 & 3.52 & 19.6 & 36.4 & 12.3 & 51.7 & 0.095 & 0.004 & 24.9 & 11.8 & 631 & 30.2 & $(0.2)$ \\
\hline $14-1,140-150$ & 120.5 & 7.98 & 2.15 & 19.7 & 36.4 & 11.1 & 51.9 & 0.094 & 0.003 & 25.1 & 11.3 & 460 & - & 0.05 \\
\hline $34-1,140-150$ & 310.5 & - & - & 20.1 & 36.7 & 17.2 & 48.5 & - & - & - & - & - & - & - \\
\hline
\end{tabular}

a Shipboard data.

b Values of $\leq 0.05 \mathrm{mM}$ are not considered significant.

$53,54,448,450$, and 451 ) there have been major contributions of volcanic materials (tuffs, ashes) to the overall sediment composition, only Sites 53 and 450 show appreciable concentration gradients. In this chapter we shall explore on a preliminary basis the reasons this may be so.

Interstitial data for Sites 53 and 450 are presented for comparison in Figure 2. Concentration-depth profiles of dissolved calcium and magnesium at Site 450 suggest that, in addition to a possible input from the underlying basalts, reactions below a depth of 200 meters are to a large extent responsible for the input of calcium and the removal of magnesium. Below 200 meters, dissolved silica values of $>700 \mu M$ are obtained, and strontium, manganese, and lithium all show distinct maxima near 200 meters depth. We postulate that in this depth horizon, alteration reactions that presumably involve volcanic matter are taking place, leading to these concentration changes. Dissolved potassium concentrations do not appear to be affected by this type of reaction, and no extremum is observed at 200 meters. The underlying basalts probably constitute the main sink for dissolved potassium.

In comparison, the Site 53 sediments show complex concentration-depth profiles for dissolved calcium and magnesium, with concentration extrema at about a depth of 25 meters. The zone of these extrema coincides with a maximum in dissolved silica, which reflects the presence of radiolarian oozes in these sediments. Extrema in dissolved strontium, lithium, and manganese also occur in this zone. Again we postulate that a zone of reaction is associated with these high silica activities and that reactions in this zone have only recently gained importance, thus leading to maxima and minima in the concentration-depth profiles. Reactions in the underlying basalts are clearly responsible for further decreases in magnesium and potassium and for the release of lithium and calcium. Dissolved potassium concentrations appears unaffected by the reaction zone at around 25 meters depth.

In general, we are impressed by the similarity of the profiles at Sites 53 and 450. A common denominator is the concentration of dissolved silica higher than 700 $\mu M$. Whereas Site 450 sediments are reported to be almost barren of radiolarian silica debris, dissolved silica values are high, probably because of the relatively high concentrations of dissolved silica associated with the abundant volcanic glass and tuffs at this site. We postulate that reactions only become feasible when dissolved silica values in excess of $700 \mu M$ are reached. This 

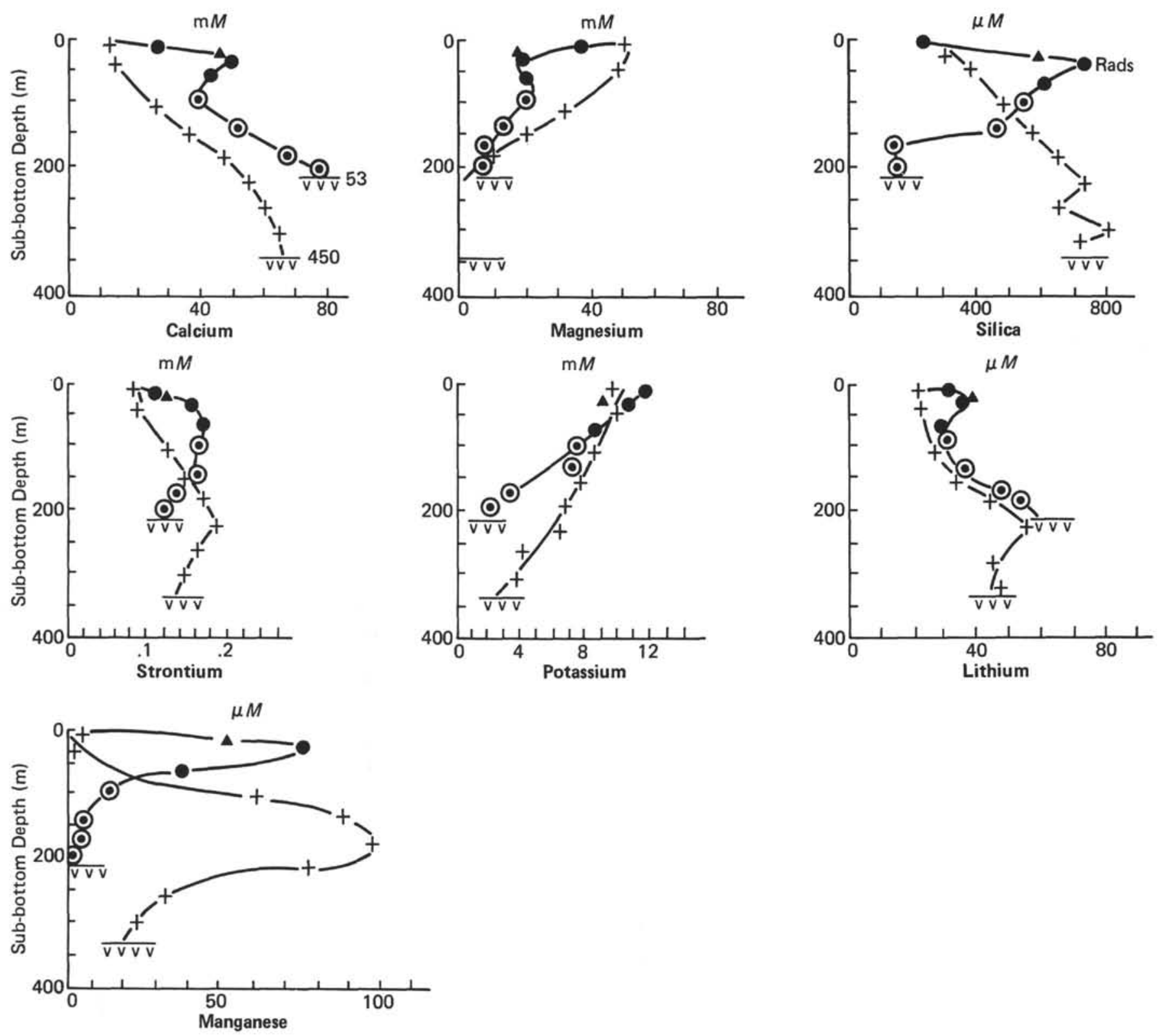

Figure 2. Interstitial water data, Sites 53 and $450(+=450 ; \bullet=53-1 ; \boldsymbol{\Delta}=53-2 ; \odot=53-0$ [Site 53, Manheim and Sayles, 1970]).

would explain the complete absence of concentration gradients at Site 54 (Manheim and Sayles, 1970) and the small gradients at Site 451 (Table 1), where dissolved silica values remain generally well below $600 \mu M$. Further studies on the sediments and interstitial waters (oxygen and strontium isotopes) of these sites are clearly warranted in order to unravel the processes involved.

\section{ACKNOWLEDGMENTS}

Shipboard analyses were carried out by Mr. John Rutherford. The manuscript was reviewed by Drs. R. E. McDuff and J. R. Lawrence, This research was supported by NSF Grant OCE 77-24102.

\section{REFERENCES}

Barnes, R. O., Gieskes, J. M., Horvath, J., et al., 1979. Interstitial water studies, Leg 47A, B. In Ryan, W. B. F., Sibuet, J.-C., et al.,
Init. Repts. DSDP, 47, Pt. 2: Washington (U.S. Govt. Printing Office), 577-582.

Gieskes, J. M., 1974. Interstitial water studies, Leg 25. In Simpson, E. S. W., Schlich, R., et al., Init. Repts. DSDP, 25: Washington (U.S. Govt. Printing Office), 361-394.

Gieskes, J. M., and Lawrence, J. R., 1976. Interstitial water studies, Leg 35. In Hollister, C. D., Craddock, C., et al., Init. Repts. $D S D P, 35$ : Washington (U.S. Govt. Printing Office), 407-424. , in preparation. Alteration of volcanic matter in deep sea sediments: evidence from the composition of interstitial waters of DSDP cores.

Luther, G. W., and Meyerson, A. L., 1975. Polarographic analysis of sulfate ion in seawater. Anal. Chem. 47:2058-2059.

Manheim, F. T., and Sayles, F. L., 1970. Interstitial water studies on small core samples, DSDP, Leg 6. In Fischer, A. G., Heezen, B. C., Init. Repts. DSDP, 6: Washington (U.S. Govt. Printing Office), 811-822. 
McDuff, R. E., 1978. Conservative behavior of calcium and magnesium in the interstitial waters of marine sediments: identification and interpretation [PhD. thesis]. University of California, San Diego.

, in preparation. Major cation gradients in DSDP interstitial waters: the role of diffusive exchange between seawater and upper oceanic crust.
McDuff, R. E., and Gieskes, J. M., 1976. Calcium and magnesium in DSDP interstitial waters: diffusion or reaction? Earth Planet. Sci. Lett. 33:1-10.

Presley, B. J., 1971. Techniques for analyzing interstitial water samples. I. Determination of selected minor and major inorganic constituents. In Winterer, E. L., Riedel, W. R., et al., Init. Repts. DSDP, 7, Pt. 2: Washington (U.S. Govt. Printing office), 1749-1755. 